\title{
OPTIMALISASI POTENSI DESA DALAM RANGKA MERINTIS DESA WISATA PARANGGUPITO KABUPATEN WONOGIRI
}

\author{
Elisa Dwi Rohani ${ }^{1}$, Yitno Purwoko ${ }^{2}$, Agus Kurniawan Darmanto ${ }^{3}$
}

\author{
${ }^{I}$ Sekolah Vokasi Universitas Gadjah mada, Yogyakarta, Indonesia, Email:elisa.dwi.rohani@ugm.ac.id \\ ${ }^{2}$ STIE Pariwisata API, Yogyakarta, Indonesia, Email: yitno.purwoko@yahoo.com \\ ${ }^{3}$ Ketua Pokdarwis Bowosemidhan Desa Wisata Paranggupito, Wonogiri, Indonesia Email: \\ aguskurniawandarmanto@gmail.com
}

\begin{abstract}
ABSTRAK
Histori Artikel

Submitted:

1 Mei 2021

Reviewed:

5 Mei 2021

Accepted:

14 Mei 2021

Published:

15 Mei 2021

Pemerintah Provinsi Jawa Tengah melalui Peraturan Daerah Provinsi Jawa Tengah No. 2 Tahun 2019 tentang pemberdayaan desa wisata menjadi salah satu dasar bagi Kabupaten Wonogiri untuk mengembangankan desa wisata. Tujuan penelitian adalah mengali potensi dan daya tarik wisata, memetakan potensi desa wisata serta, Menyusun konsep desa wisata dengan aktivitas yang ditawarkan strategi mengemas desa wisata menjadi produk paket wisata. Pada penelitian ini megunakan metode penelitian Kualitatif deskriptif dengan mengambarkan dan memetakan potensi desa wisata, serta menyusun paket wisata desa. Selain itu pembangunan non fisik juga akan dilakukan meliputi pembangunan SDM baik ketrampilan Teknik maupun manajerial bagi pengelola desa wisata, membangun jejaring Kerjasama, dan menyusun media pemasaran yang akan digunakan. 2 konsep yang diusulkan dalam merintis desa wisata Paranggupito yaitu berorentasi pada pasar wisatawan yang akan dituju, konsep wisata edukasi dan petualangan dengan pasar yang dituju adalah anak muda yang menyukai petualangan.
\end{abstract}

Kata Kunci: Optimalisasi, Potensi, Desa Wisata, Paranggupito

\section{OPTIMIZATION OF VILLAGE POTENTIAL IN THE ORDER OF PIONEERING PARANGGUPITO TOURISM VILLAGE, WONOGIRI REGENCY}

\section{ABSTRACT}

Central Java Provincial Government through Central Java Provincial Regulation No. 2 of 2019 concerning the empowerment of tourist villages is one of the foundations for Wonogiri Regency to develop tourist villages. The purpose of the research is to explore the potential and attractiveness of tourism, map the potential of tourist villages and, develop the concept of a tourist village with the activities offered by the strategy of packaging tourist villages into tourism package products. This study uses descriptive qualitative research methods to describe and map the potential of tourist villages, as well as develop village tour packages. In addition, non-physical development will also be carried out including the development of human resources, both technical and managerial skills for tourism village managers, building cooperation networks, and compiling marketing media to be used. The 2 concepts proposed in pioneering the tourist village of Paranggupito are oriented towards the tourist market to be addressed, the concept of educational and adventure tourism.

Keywords : Optimization, Potential, Tourism Village, Paranggupito 


\section{PENDAHULUAN}

Menteri Desa, Pembangunan Daerah Tertinggal, Dan Transmigrasi Republik Indonesia melalui Peraturan Menteri Desa, Pembangunan Daerah Tertinggal, Dan Transmigrasi Republik Indonesia Nomor 11 Tahun 2019 Tentang Prioritas Penggunaan Dana Desa Tahun 2020 menyebutkan bahwa salah satu kegiatan prioritas bidang pembangunan desa adalah Pengadaan, pembangunan, pemanfaatan dan pemeliharaan sarana dan prasarana Desa Wisata. Desa wisata menjadi prioritas pengunaan dana desa karena dirasa cukup mampu memberikan manfaat bagi masyarakat desa melalui peningkatan kualitas hidup, peningkatan kesejahteraan, penanggulangan kemiskinan, dan peningkatan pelayanan publik.

Seiring dengan perkembangan desa wisata, Pemerintah Provinsi Jawa Tengah merespon kondisi ini dengan adanya Peraturan Daerah Provinsi Jawa Tengah No. 2 Tahun 2019 tentang pemberdayaan desa wisata di Provinsi Jawa Tengah disebutkan bahwa Desa Wisata adalah suatu bentuk integrasi antara potensi daya tarik wisata alam, wisata budaya, dan wisata hasil buatan manusia dalam satu kawasan tertentu dengan didukung oleh atraksi, akomodasi, dan fasilitas lainnya sesuai kearifan lokal masyarakat. Oleh sebab itu, dengan adanya peraturan daerah ini Pemerintah Provinsi Jawa Tengah berupaya untuk mengembangkan pariwisata sebagai salah satu penggerak perekonomian daerah baik pada skala provinsi guna mewujudkan dampak ekonomi melalui pemberdayakan seluruh potensi wisata di Desa dengan membentuk dan mengembangkan Desa Wisata.

Provinsi Jawa Tengah adalah salah satu provinsi besar yang memiliki lokasi strategis di Pulau Jawa. Karena lokasinya yang strategis dan berada di tengah-tengah jalur darat, maka Provinsi Jawa Tengah ramai dikunjungi orang-orang yang dalam perjalanan menuju kota lain untuk singgah sejenak. Secara administratif, potensi pariwisata di Provinsi Jawa Tengah terbagi dalam 29 kabupaten dan 6 kota dengan luas wilayah Jawa Tengah sebesar 3,25 juta hektar atau sekitar 25,04 persen dari luas Pulau Jawa (1,70 persen luas Indonesia) . Masing-masing kabupaten dan kota memiliki daya tarik wisata yang sangat beragam, baik wisata alam, wisata budaya, wisata belanja, kuliner, religius, maupun berbagai festival dan event-event yang secara khusus bertujuan untuk menarik wisatawan. Tidak hanya menjadi favorit bagi wisatawan nusantara, Provinsi Jawa Tengah juga menjadi destinasi wisatawan mancanegara. Beragam daya tarik wisata menjadi faktor pendorong wisatawan untuk mengunjungi Provinsi Jawa Tengah salah satunya adalah Desa Wisata. Berdasarkan data Dinas Kepemudaan, Olahraga, dan Pariwisata Jawa Tengah 2019, jumlah desa wisata di Jawa Tengah mengalami peningkatan. Berikut data desa wisata dan pokdarwis yang ada di Provinsi Jawa Tengah

Tabel 1 Jumlah Pokdarwis Dan Desa Wisata Homestay Di Jawa Tengah

\begin{tabular}{cccc}
\hline Tahun & $\begin{array}{c}\text { Pokdar } \\
\text { wis }\end{array}$ & Desa wisata & Homestay \\
\hline $\mathbf{2 0 1 4}$ & 336 & 126 & 823 \\
\hline $\mathbf{2 0 1 5}$ & 409 & 126 & 823 \\
\hline $\mathbf{2 0 1 6}$ & 645 & 146 & 823 \\
\hline $\mathbf{2 0 1 7}$ & 448 & 182 & 765 \\
\hline $\mathbf{2 0 1 8}$ & 650 & 229 & 765 \\
\hline
\end{tabular}

Sumber ; Neraca Satelit Pariwisata Daerah Provinsi Jawa Tengah, Dinas Kepemudaan, Olahraga, Dan Pariwisata Jawa Tengah 2019

Salah satu Kabupaten di Jawa Tengah berada di ujung selatan yang saat ini sedang berupaya membangun desa wisata adalah Kabupaten Wonogiri. Kabupaten Wonogiri memiliki luas wilayah $1822,37 \mathrm{~km}^{2}$ terdiri dari 25 kecamatan dan 297 desa atau kelurahan. Wilayah Wonogiri yang cukup luas memilik potensi wisata yang sangat beragam baik potensi alam diantaranya adalah gunung, pantai, lahan pertanian, gua, serta potensi budaya, termasuk didalamnya adalah potensi desa wisata. Meskipun jumlah desa dan kelurahan di Wonogiri mencapai 297 desa, namun tidak semua desa 


dikembangkan dan dibina untuk menjadi
desa wisata. Berikut data Desa wisata yang
ada di Wonogiri

Table 2 Desa Wisata Kabupaten Wonogiri

\begin{tabular}{|c|c|c|}
\hline Kecamatan & $\begin{array}{c}\text { Jumlah } \\
\text { Kelura } \\
\text { han }\end{array}$ & Desa wisata \\
\hline Pracimantoro & 18 & Tidak ada \\
\hline Paranggupito & 8 & $\begin{array}{l}\text { Desa } \\
\text { Wisata } \\
\text { Paragupit } \\
\text { o }\end{array}$ \\
\hline Giritontro & 7 & Tidak ada \\
\hline Giriwoyo & 16 & Tidak ada \\
\hline Batuwarno & 8 & $\begin{array}{l}\text { Desa } \\
\text { Wisata } \\
\text { Sumberej } \\
\text { o }\end{array}$ \\
\hline Karangtengah & 5 & Tidak ada \\
\hline Tirtomoyo & 14 & Tidak ada \\
\hline Nguntoronadi & 11 & $\begin{array}{l}\text { Tidak } \\
\text { ada }\end{array}$ \\
\hline Baturetno & 13 & $\begin{array}{l}\text { Tidak } \\
\text { ada }\end{array}$ \\
\hline Eromoko & 15 & $\begin{array}{l}\text { Tidak } \\
\text { ada }\end{array}$ \\
\hline Wuryantoro & 9 & $\begin{array}{l}\text { Tidak } \\
\text { ada }\end{array}$ \\
\hline Manyaran & 7 & $\begin{array}{l}\text { Desa } \\
\text { Wisata } \\
\text { Kepuhsa } \\
\text { ri, Desa } \\
\text { Wisata } \\
\text { Karanglo } \\
\text { r }\end{array}$ \\
\hline Selogiri & 11 & $\begin{array}{l}\text { Tidak } \\
\text { ada }\end{array}$ \\
\hline Wonogiri & 15 & $\begin{array}{l}\text { Desa } \\
\text { Wisata } \\
\text { Sedang }\end{array}$ \\
\hline Ngadirjo & 11 & $\begin{array}{l}\text { Tidak } \\
\text { ada }\end{array}$ \\
\hline Sidoharjo & 12 & $\begin{array}{l}\text { Tidak } \\
\text { ada }\end{array}$ \\
\hline Jatiroto & 14 & $\begin{array}{l}\text { Tidak } \\
\text { ada }\end{array}$ \\
\hline Kismantoro & 10 & $\begin{array}{l}\text { Tidak } \\
\text { ada }\end{array}$ \\
\hline Purwantoro & 15 & $\begin{array}{l}\text { Tidak } \\
\text { ada }\end{array}$ \\
\hline Bulukerto & 10 & $\begin{array}{l}\text { Desa } \\
\text { Wisata } \\
\text { Conto }\end{array}$ \\
\hline Pohpelem & 6 & $\begin{array}{l}\text { Tidak } \\
\text { ada }\end{array}$ \\
\hline
\end{tabular}

\begin{tabular}{|c|c|c|}
\hline Selogohimo & 17 & $\begin{array}{l}\text { Tidak } \\
\text { ada }\end{array}$ \\
\hline Jatisrono & 16 & $\begin{array}{l}\text { Tidak } \\
\text { ada }\end{array}$ \\
\hline Jatipurwo & 15 & Tidak ada \\
\hline Girimarto & 16 & Tidak ada \\
\hline
\end{tabular}

Table diatas memberikan gambaran banyaknya desa dan kelurahan pada masingmasing kecamatan dengan karakteristik wilayah dan potensi alam dan budaya yang beragam, namun sebaran desa yang ada di Kabupaten Wonogiri ini, belum dimanfaatkan secara maksimal untuk merintis desa wisata. Saat ini Kabupaten Wonogiri memilik 6 desa wisata yang telah memilik SK sebagai desa wisata dari Dinas Kepemudaan Dan Olahraga Dan Pariwisata Kabupaten Wonogiri ditahun 2020 pada 5 kecamatan berbeda yaitu Kecamatan Paranggupito yaitu Desa wisata Paranggupito, Kecamatan Batuwarno yaitu desa Wisata Sumberejo, sedangkan untuk Kecamatan Manyaran terdapat dua desa wisata yaitu Desa Wisata Kepuhsari dan Desa Wisata Karanglor, Kecamatan Wonogiri yaitu Desa Sedang, dan Kecamata Bulukerto yaitu Desa Wisata Conto. Penelitian ini akan dilakukan pada salah satu Desa Wisata di Kabupaten Wonogiri yang telah dibina oleh Dinas Kepemudaan Dan Olahraga Dan Pariwisata Kabupaten Wonogiri yang terletak di sisi selatan Wonogiri adalah Desa Wisata Paranggupito.

\section{LITERATUR REVIEW}

Desa wisata menjadi topik pembahasan yang banyak diperbincangan pada dunia pariwisata saat ini, sehingga penelitian terkait tentang desa wisata telah banyak dilakukan oleh peneliti sebelumnya. Penelitian yang dilakukan oleh (Anggit \& Suswanta, 2020) berjudul Pengembangan Desa Wisata Berbasis Pemberdayaan Masyarakat Desa Wisata Kaki Langit Padukuhan Mangunan menemukan bahwa dengan dilibatkan secara langsung saat ini masyarakat merasakan dampak ekonomi dengan tambahan 
pendapatan yang mereka dapat. Penelitian ini menggunakan metode deskriptif kualitatif. Hasilnya, pariwisata lokal melalui pengembangan desa wisata Pemberdayaan Masyarakat mampu memberikan dampak ekonomi bagi masyarakat.

Penelitian dengan judul Identifikasi Potensi dan Status Pengembangan Desa Wisata di Kabupaten Lombok Tengah, Nusa Tenggara Barat yang dilakukan oleh (Azhar, et al., 2020) memberi gambaran bahwa aspek atraksi dan aksesibilitas baik untuk mendukung dan pengembangan desa wisata, sedangkan aspek amenitas, kesiapan masyarakat dan lembaga pengelola masih belum optimal.Badan Usaha Milik Desa (BUMDesa) dan Kelompok Sadar Wisata belum optimal untuk mendukung keberlanjutan desa wisata. Begitu halnya dengan promosi yang belum berjalan dengan baik,sehingga dukungan dari pemerintah dan asosiasi sangat diperlukan. Destinasi Desa Sade dan Desa Ende berstatus desa maju dengan atraksi adat budaya Suku Sasak. Desa tersebut sudah lama terbentuk dan dikunjungi oleh wisatawan nusantara dan wisatawan mancanegara.

Penelitian ketiga yang dilakukan oleh (Ramang, et al., 2020) berjudul Sustainable Tourist Villages Management Based On Javanese Local Wisdom 'Memayu Hayuning Bawono Best Practice Of Desa Wisata Pentingsari, Yogyakarta Hasil penelitian menemukan bahwa pariwisata dan kearifan lokal telah menjadi satu kesatuan dan seolaholah saling memperkuat. Dengan kata lain, harmonisasi antara aspek lingkungan, seni budaya, dan kehidupan masyarakat melalui kearifan lokal, dapat menjadi komoditas pariwisata. Di sisi lain, pariwisata memberikan dampak ekonomi dan sosial untuk melestarikan rasa lokal masyarakan.

Dari ketiga penelitian ini yang memilik fokus penelitian tentang desa wisata, namun memilik perbedaan pada masing-masing penelitian. Jika peneliti pertama melihat bentuk dan dampak keterlibatan masyarkat pada desa, sedangkan penelitian ke dua lebih kepada identifikasi potensi desa wisata dengan mengunakan aspek 3 A (atraksi, aksesbilitas, dan amenitas), dan penelitian terakhir lebih menekankan pada kearifkan lokal sebagai daya tarik yang saling menguatkan. Sedangkan penelitian ini akan fokus pada merintis desa wisata dengan memaksimalkan potensi yang ada. Tujuan penelitian adalah mengali potensi dan daya tarik wisata, memetakan potensi desa wisata, serta, Menyusun konsep desa wisata dengan aktivitas yang ditawarkan strategi mengemas desa wisata menjadi produk paket wisata.

\section{METODE}

Pada penelitian ini megunakan metode penelitian Kualitatif deskriptif dengan mengambarkan dan memetakan potensi desa wisata, serta menyusun paket wisata desa. Lokasi Penelitian ini berada di Desa Wisata Paranggupito, salah satu desa yang berada di sebelah selatan Kabupaten Wonogiri. Pengumpulan data dilakukan dengan observasi lapangan yang telah dilaksanakan pada akhir tahun 2020, wawancara mendalam yang akan dilakukan dengan 1) Dinas Kepemudaan Dan Olahraga Dan Pariwisata Kabupaten Wonogiri, 2) kepala desa, 3) pokdarwis desa wisata, 4) sesepuh desa, 5) pengiat budaya dan pariwisata desa, serta 6) masyarakat sebagai pelaku wisata. Pengumpulan data juga dilakukan dengan Focus Group Discussion (FGD) untuk menjaring dan merekam informasi pikiran kolektif masyarakat, yang diwakili oleh kelompok atau individu-individu yang memiliki hubungan langsung dengan pengelolaan.

\section{HASIL DAN PEMBAHASAN}

\section{Profil Desa Wisata Paranggupito}

Desa Paranggupito adalah desa yang terletak di sisi selatan Kabupaten Wonogiri. Secara administratif desa ini terletak di Kecamatan Paranggupito, Wonogiri, Jawa Tengah. Desa yang berada di titik koordinat 110.8485 LS/LU 8.18806 BT/BB ini adalah salah satu desa di ujung selatan Kab. Wonogiri yang 
sebelah utara berbatasan dengan Desa Ketos, timur berbatasan dengan Desa Gudangharjo dan Sambiharjo, sedangkan sebelah barat berbatasan dengan Desa Ketos dan Songbanyu-DIY, sebelah selatan berbatasan langsung dengan Samudera Hindia. Desa Paranggupito dapat diakses menggunakan kendaraan roda dua maupun roda empat dengan kondisi jalan yang cukup baik. Berikut gambaran wilayah desa wisata Paranggupito

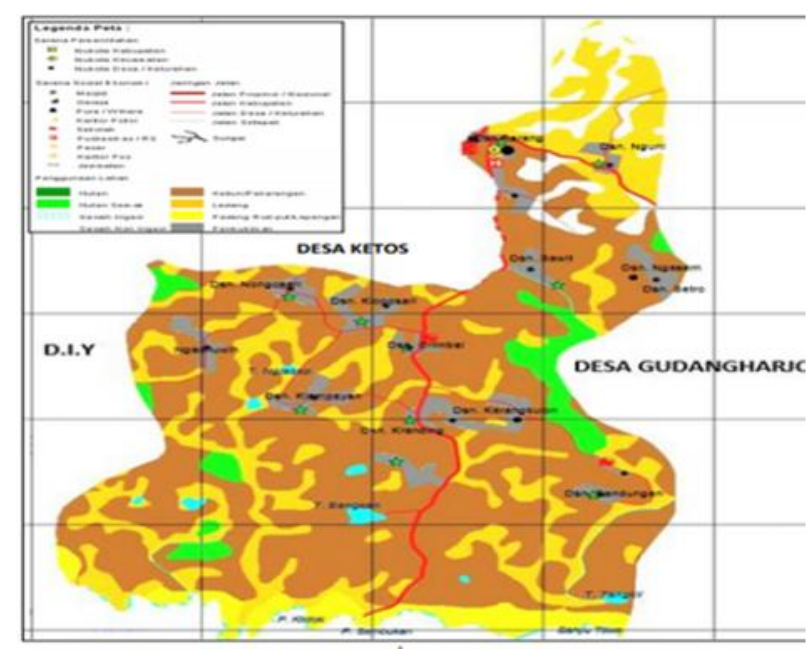

Gambar 1. Gambaran wilayah desa wisata paranggupito

Sumber ; Profil Desa Paranggupito, 2020

Desa Paranggupito terletak pada ketinggian $625 \mathrm{mdpl}-1.500 \mathrm{mdpl}$ dengan geomorfologi perbukitan sehingga memiliki beragam titik ketinggian dengan beberapa titik memiliki kontras yang tajam dari sekitarnya. Dengan kata lain, desa ini memiliki beberapa jurang dan tebing. Desa Paranggupito memiliki 1 sumber mata air yang terletak di tepi laut selatan tepatnya di Pantai Banyu Towo. Karena keterbatasan biaya dan SDM maka ketersediaan sumber air ini belum dapat dimanfaatkan secara maksimal. Curah hujan di wilayah ini rata - rata $400 \mathrm{~mm}$ per tahun dengan suhu udara rata - rata 20 o C. Pada musim kemarau, ketersediaan air kurang mencukupi kebutuhan masyarakat dan suhu udara dapat mencapai suhu terendah.

Desa Paranggupito termasuk kedalam satuan geologi lingkungan perbukitan yang agak terjal dan lingkungan perbukitan berlereng terjal. Perbukitan agak terjal memiliki kemiringan 15 - $25 \%$ yang tersusun oleh litologi batu pasir, batu lempung, dan sebagian kecil batuan beku, breksi, dan lahar. Secara umum daerah ini digunakan sebagai lahan perkebunan, lahan pertanian, tanaman keras tahunan, tegalan, dan pemukiman. Daerah yang termasuk perbukitan berlereng terjal memiliki kemiringan $25-40 \%$ tersusun oleh batuan beku, breksi, tufa, konglomerat. Lahan pada daerah ini digunakan sebagai kawasan pertanian, hutan, dan perkebunan. Litologi karst (batugamping) juga terdapat di Desa Paranggupito dengan kenampakan goa yang di dalamnya dapat dijumpai stalaktit dan stalakmit.

Masyarakat Desa Paranggupito adalah masyarakat berbudaya yang sampai saat ini masih melestarikan berbagai budaya Jawa seperti kenduri, tahlilan, sepasaran dan rasulan/bersih dusun. Selain itu, kesenian tradisional seperti jathilan, wayang kulit dan gamelan masih hidup dan dilestarikan. Nilainilai budaya Jawa seperti sikap yang ramah terhadap siapapun juga masih tetap dijunjung tinggi. Keadaan sosial dalam kehidupan masyarakat terbilang cukup kondusif. Kerukunan warga dapat terlihat ketika masyarakat bergotong royong membangun infrastruktur umum dan sambatan. Warga Desa Paranggupito secara umum berprofesi sebagai petani, nelayan dan pedagang, sedangkan kebanyakan angkatan kerja pergi merantau keluar desa karena kurangnya lapangan kerja. Para perantau ini kebanyakan memilih merantau demi mencukupi kebutuhan keluarga. Hal ini berdampak pada permasalahan sosial yakni kurang sempurnanya pendidikan anak yang berakibat pada maraknya pernikahan dini serta banyaknya anak yang enggan melanjutkan sekolah ke jenjang yang lebih tinggi.

\section{Potensi Alam Desa Wisata Paranggupito}

Paranggupito berada di wilayah sisi selatan Kabupaten Wonogiri dan masuk dalam Jaringan Global Geopark Network yang meliputi 3 Provinsi berbeda yaitu Yogyakarta di Kabupaten Gunungkidul, Jawa Tengah di 
Kabupaten Wonogiri, serta Jawa Timur di Kabupaten Pacitan. Kabupaten Wonogiri memilik 7 geosite diantaranya adalah sebagai berikut

Table 3 Geosite Kabupaten Wonogiri

\begin{tabular}{cc}
\hline Geosite & \multicolumn{1}{c}{ Lokasi } \\
\hline Lembah Purba & $\begin{array}{c}\text { Ds. Giritontro Kec. } \\
\text { Giritontro }\end{array}$ \\
\hline Gua Sodong & $\begin{array}{c}\text { Ds. Gebangharjo, Kec. } \\
\text { Pracimantoro }\end{array}$ \\
\hline Gua Tembus & $\begin{array}{c}\text { Ds. Gebangharjo, Kec. } \\
\text { Pracimantoro }\end{array}$ \\
\hline Luweng Sapen & $\begin{array}{c}\text { Ds. Gebangharjo, Kec. } \\
\text { Pracimantoro }\end{array}$ \\
\hline Gua Mrico & $\begin{array}{c}\text { Ds. Gebangharjo, Kec. } \\
\text { Pracimantoro }\end{array}$ \\
\hline Gua Potro-Bunder & $\begin{array}{c}\text { Ds. Gebangharjo, Kec. } \\
\text { Pracimantoro }\end{array}$ \\
\hline
\end{tabular}

Sumber : Application Dossier for Membership to UNESCO Global Geopark Network, 2013

Berdasarkan table diatas terlihat bahwa salah satu potensi alam yang ada di desa wisata Paranggupito masuk dalam geosite yaitu Pantai Sembukan, kondisi ini menjadi peluang bagi daya tarik pantai sejenis yang berada di sekitar Kawasan Pantai Sembukkan. Desa wisata Paranggupito tidak hanya memilik potensi alam, namun juga potensi budaya yang dapat dikembangkan sebagai atraksi wisata. Berada di Kawasan selatan yang merupakan daerah pesisir pantai, Desa wisata Paranggupito memilik banyak potensi wisata pantai diantaranya adalah :

\section{Pantai Sembukan}

Pantai ini secara administratif terletak di Dusun Kranding. Akses jalan menuju ke pantai sudah bagus dan bisa dilalui kendaraan baik roda 2 maupun roda 4. Pantai ini dikenal sebagai tempat untuk melaksanakan ritual kejawen yang dilaksana setiap 1 suro yaitu selamatan Larung Ageng baik oleh Kraton Surakarta, mayarakat setempat dan masyarakat diluar desa Paranggupito yang memilik tujuan spiritual. Selain sebagai lokasi ritual, Pantai Sembukan juga mempunyai pemandangan yang sangat indah, dan batuan yang unik dan merupakan salah satu pantai yang masuk dalam Kawasan perbukitan Geopark Gunungsewu. Pantai Sembukan juga merupakan salah satu objek wisata spiritual yang dilengkapi beberapa sarana ibadah antara lain masjid, paseban dan sanggar, namun sayangnya bibir pantai tidak terlalu luar. Menurut mitos, pantai ini merupakan pintu gerbang ke-13 Kerajaan Ratu Kidul yang digunakan oleh Kanjeng Ratu Kidul untuk menghadiri pertemuan dengan raja-raja Kasunanan Surakarta (Paku Buwono).

\section{Pantai Klotok}

Pantai ini secara administratif terletak di Dusun Kranding berlokasi di sebelah barat Pantai Sembukan. Pada tahun 2006 melalui Pemda Wonogiri telah dibangun dermaga dan tempat pelelangan ikan (TPI) serta bangunan permanen untuk pemecah ombak, namun tidak berfungsi sebagaimana yang diharapkan. Kondisi bibir pantai yang sempit dan adanya bangunan pemecah ombak membuat pantai ini tidak menawarkan aktivitas pantai untuk bermain air mengingat kondisi pantai dengan ombak yang cukup tinggi. Salah satu kendala tidak berporasinya dermaga di pantai ini adalah ombak yang terlalu besar dan banyaknya bebatuan karang di sebelah kanan dan kiri pantai. Namun demikian, pantai ini memilik pemandangan alam yang mampu memikat wisatawan berupa pemandang pantai yang diapit perbukitan di kanan dan kiri pantai.

\section{Pantai Njojogan}

Pantai Njojogan terletak di Dusun Klampeyan Desa Paranggupito. Panorama yang terdapat di Pantai Njojogan adalah keindahan bentang alam pegunungan karst Gunung Sewu, hamparan batuan karang berselimut rumput laut yang terkikis abrasi hingga membentuk cekungan kecil memanjang ke arah pantai serta pasir putihnya di sepanjang garis pantai. Menariknya pantai ini memilik batuan karang seperti jamur karena proses alamiah terkikis oleh air laut selain itu di pantai ini menjadi lokasi strategis untuk mencari hewan biota laut dan rumput laut untuk dijadikan laukpauk. Namun sayangnya, akses menuju pantai Njojogan masih berupa jalan setapak dengan melewati perbukitan karst yang unik dan menarik. 


\section{Pantai Ndadapan (Mangetan)}

Pantai Ndadapan terletak diperbatasan antara Kabupaten Wonogiri (Provinsi Jawa tengah) dengan Kabupaten Gunungkidul (Provinsi DIY), Pantai Mangetan atau yang sering juga dikenal dengan nama Pantai Dadapan merupakan pantai paling barat Wonogiri yang masih alami dan jarang dikunjungi wisatawan. Berada di Desa Paranggupito, Kecamatan Paranggupito, lokasi pantai ini tidak jauh dari Pantai Sembukan. Pantai ini memiliki garis pantai yang terbilang sempit dibandingkan pantai lain di Paranggupito, namun pantai ini memiliki keunikan tersendiri yaitu berupa bebatuan karang yang mengapit pantai berpasir putih dan air laut yang jernih berwarna kebiruan. Berikut gambaran pantai di Desa wisata Paranggupito

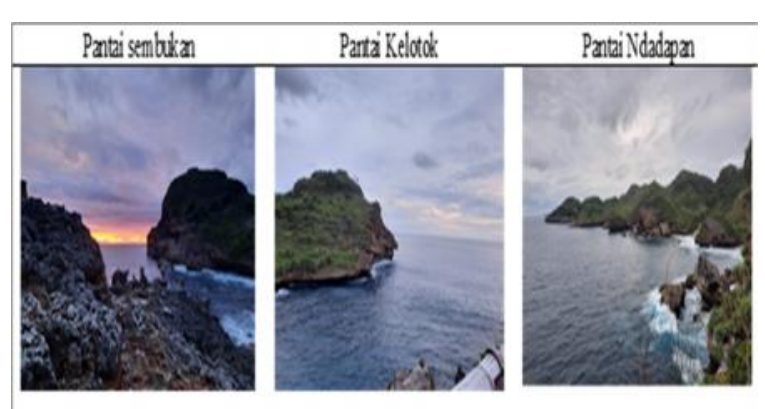

Gambar 2 Potensi Wisata Pantai Desa Wisata Paranggupito

Sumber ; Dokumentasi Penelitian, 2020

\section{Spot Rock Fishing}

Pesisir pantai selatan yang berada di desa Paranggupito memilik karakteristik pantai berbatu dan tebing tinggi bahan perbukitan karst, sehingga kondisi ini sangat mendukung untuk pecinta spot rock fishing. Kegiatan ini merupakan memancing yang dilakukan di atas tebing atau karang diatas laut, yang bisa dilakukan pada saat sore, malem dan pagi hari. Salah satu hasil memancing di kawasan pantai selatan Paranggupito yang memilik nilai jual tinggi dan mampu menarik minat pemancing adalah Lobster. Ada beberapa spot rock fishing yang dikenal dengan Pathuk dan sering digunakan para penggemar rock fishing baik lokal Paranggupito maupun dari daerah lain diantaranya adalah Pathuk Mlinas, Pathuk Nglojok, Pathuk

\section{Potensi Seni dan Budaya Desa Wisata Paranggupito}

Saat ini Desa Paranggupito memiliki kesenian tradisional yang cukup aktif yakni Karawitan, Jatilan, Trethek, Tembang Jawa Dan Gejug Lesung. Masing - masing memiliki keunikkan yang berbeda untuk dinikmati dan juga sudah memiliki kelompok atau sanggar serta tidak jarang menggelar pertunjukkan. Meski begitu, masyarakat memiliki rencana untuk menghidupkan kembali budaya - budaya yang telah punah sepeti permainan tradisional Jawa. Potensi budaya yang potensial menjadi atraksi wisata diantaranya adalah ;

\section{Larung Agung}

Larung agung merupakan tardisi yang telah dilakukan turun-menurut bagi masyarakat desa Paranggupito yang dilaksanakan setiap malam 1 Suro. Tradisi ini tidak hanya dilakukan masyarakat setempat namun juga mampu menarik warga dari berbagai daerah yang memilik kepercayaan Kejawen. Tradisi ini dilakukan di Pantai Sembukan dengan cara melarung (menghanyutkan) sesaji yang berisi hasil bumi dari masyarakat setempat serta dilakukan pada sore hari menjelang matahari terbenam. Tradisi ini mampu mendatangkan wisatawan dari Jawa Tengah dan sekitarnya, sehingga tradisi ini layak untuk menjadi atarksi wisata budaya yang dapat dinikmati wisatawan setiap tahun.

Rasulan (bersih desa)

Rasulan atau Bersih Dusun dilakukan oleh masing-masing dusun di kecamatan Paranggupito sebagai bentuk rasa syukur atas keselamatan dan hasil panen. Tradisi ini dilaksanakan setiap satu tahun sekali dan berlangung beberapa hari diawali dengan membersihkan dan membangun lingkungan desa dan diramaikan dengan pawai budaya, kirab tumpeng, pagelaran wayang kulit, pertandingan olehraga modern dan tradisional, pengajian akbar dan lain-lain. Event ini digelar di bulan Besar / Dzulhijjah di tiap tahunnya, prosesi rasulan diawali dengan kirab gunungan hasil bumi. Sebelum kirab, seluruh warga berkumpul di balai 
dusun, setelah tiba waktunya kirab yang dipimpin juru kunci bergerak menuju tempat di mana wilujengan digelar di rumah kepala dusun.

\section{Karawitan}

Selain tradisi desa wisata Paranggupito juga memilik potensi seni pertunjukan yang dapat disajikan sebalah salah satu atraksi wisata dengan memainkan seperangkat alat gamelan dan diiring nyanyian jawa. Kesenian karawitan ini berada di Dusun Kranding Desa Paranggupito, desa wisata Paranggupito sendiri memilik kelompok-kelompok kesenian yang aktif dan didominasi oleh warga dewasa khususnya ibu-ibu. Kesenian Karawitan di desa Paranggupito menjadi media untuk merekatkan dan membangun kebersamaan antar warga desa wisata Paranggupito hal ini disebabkan karena latihan yang dilakukan secara rutin yaitu seminggu sekali, meskipun tidak ada pertunjukkan.

\section{Jatilan}

Selain Karawitan Desa Wisata Paranggupito memilik seni pertunjukan tari yaitu Jatilan Pujonggo Mudho yang berada di dusun Setro. Jatilan ini dimainkan oleh Pria dan wanita, namun tidak mengandung unsur magis dalam pertunjukkannya. Kesenian ini tidak hanya menampilkan tarian Jatilan namun juga Kuda lumping, serta Barongan, disetiap pertunjukkan diiring dengan music dan tembang jawa. Biasanya sebelum pertunjukkan dimulai dilaksanakan doa bersama dan mempersiapkan sesaji agar pertunjukkan berjalan dengan lancar.

\section{Tembang Jawa}

Kesenian olah vokal tembang jawa juga dapat ditemukan di Dusun Sawit, desa Paranggupito. Nama kelompok Tembang Jawa yang ada di desa Paranggupito adalah Laras Madyo dengan jumlah anggota 25-30 orang. Tembang Jawa yang disajikan adalah tembang Jawa Klasik dan tembang dolanan. Warga setempat yang masuk dalam paguyuban ini rata-rata adalah orang tua yang sudah berusia lanjut.

\section{Gejug lesung dan Trethek}

Kesenian lain yang tidak kalah menarik di desa Paranggupito adalah Kesenian Gejug lesung dan Trethek. Kesenian ini tumbuh dan berkembang di desa Paranggupito sampai saat ini. Gejug Lesung merupakan permainan instrument musik dengan mengunakan alat tardisonal yaitu penumpuk padi yang terbuat dari kayu, oleh sebab itu gejug lesung ini biasa dimainkan oleh ibuibu. Sedangkan Tretek merupakan permainan instrument musik dengan mengunakan alat music yang terbuat dari bambu Kentong Trethek dan di mainkan oleh pria.

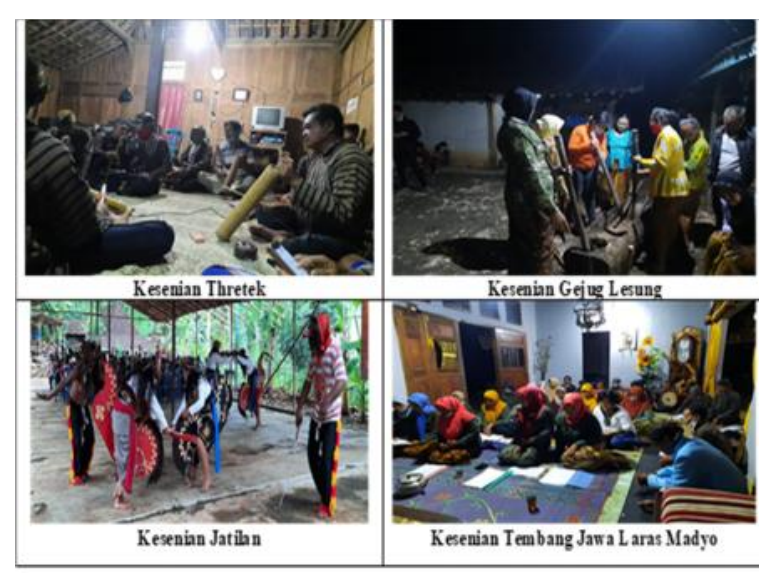

Gambar 3 Potensi Seni Budaya Desa Wisata Paranggupito

Sumber ; Dokumentasi Penelitian, 2020

Selain potensi alam dan potensi seni budaya Desa Wisata Paranggupito potensi industri rumah tangga yang dapat dikunjungu wisatawan dan masuk dalam paket wisata berupa kerajinan Bonsai, Gula Jawa dan Wisata Kuliner Pasar Pelangi. Pasar kuliner yang digelar setiap hari Minggu Pagi mulai jam 06.00 - 09.00 WIB di ruas jalan utama Desa Paranggupito. Disamping itu desa wisata Paranggupito sudah terbentuk sebuah tim pemandu outbond yang bernama P-Toe Organizar, dan sudah menerima serta memandu klien baik lokal maupun dari daerah lain. 


\section{Konsep Dalam Merintis Desa Wisata Paranggupito}

Untuk dapat dikategorikan sebagai desa wisata harus memenuhi beberapa syarat utama sebagai berikut: a. Memiliki persyaratan sebagai sebuah destinasi pariwisata sebagaimana diatur dalam UU No. 10 tahun 2009; disebutkan bahwa b. Kegiatan pariwisata berbasis pada sumber daya perdesaan; c. Kegiatan melibatkan partisipasi aktif wisatawan dalam kehidupan perdesaan; d. Lebih berorientasi pada kegiatan rekreasi luarruang (outdoor recreation); e. Sebesar-besarnya mendayagunakan sumber daya manusia lokal; f. Memberikan penghargaan besar pada budaya dan kearifan lokal; g. Menyediakan akses yang memadai baik akses menuju ke destinasi lain maupun internal di dalam desa wisata itu sendiri; dan h. Memiliki komunitas yang peduli pada pariwisata.

Pembangunan Desa Wisata Paranggupito bertujuan untuk mengoptimalkan potensi wisata di Desa Paranggupito baik wisata alam maupun kearifan budaya. Optimalisasi yang dimaksud adalah dibangunnya obyek obyek wisata yang tersebar di Desa Paranggupito dan selanjutnya akan diintegrasi menjadi satu destinasi wisata yakni "Desa Wisata Paranggupito". Hadirnya Desa Wisata Paranggupito diharapkan dapat membuka lapangan pekerjaan yang luas sehingga masyarakat Desa Paranggupito dan sekitarnya dapat bekerja tanpa harus merantau.

Kepengelolaan Desa Wisata Paranggupito akan dirancang sedemikian rupa dengan prinsip "Dari Paranggupito, Oleh Paranggupito, dan Untuk Paranggupito" sehingga keuntungan ekonomi dapat dinikmati terutama oleh seluruh masyarakat Desa Paranggupito. Dengan demikian, maka masyarakat Desa Paranggupito dapat menjadi masyarakat yang mampu mencukupi kebutuhannya secara mandiri. Pada akhirnya, Desa Wisata Paranggupito akan meningkatkan kesejahteraan masyarakat baik kesejahteraan sosial maupun kesejahteraan ekonomi.

Desa Wisata Paranggupito dirancang dengan identitas Wisata Edukasi Alam dan Budaya. Wisatawan akan diberikan ilmu pengetahuan tentang segala sesuatu yang ada pada obyek wisata alam dan obyek wisata budaya. Selain menikmati keindahan alam dan pertunjukan seni dan budaya, wisatawan akan diajak untuk belajar merawat dan mengelola alam serta melestarikan seni budaya. Setiap obyek wisata memiliki konten yang berbeda-beda sehingga wisatawan memiliki banyak pilihan wisata yang tidak membosankan. Wisata Edukasi Alam dan Budaya adalah identitas destinasi wisata yang dipilih, sebab Desa Wisata Paranggupito ingin hadir sebagai destinasi wisata yang tidak hanya menyuguhkan pemandangan saja namun juga ilmu pengetahuan praktis tentang segala sesuatu yang menjadi obyek-obyek wisata. Secara kongkret, wisatawan akan memiliki tambahan ilmu setelah berkunjung ke Desa Wisata Paranggupito disamping mendapatkan pengalaman wisata yang menyenangkan. Berikut 2 konsep yang akan digunakan dalam merintis Desa Wisata Paranggupito 

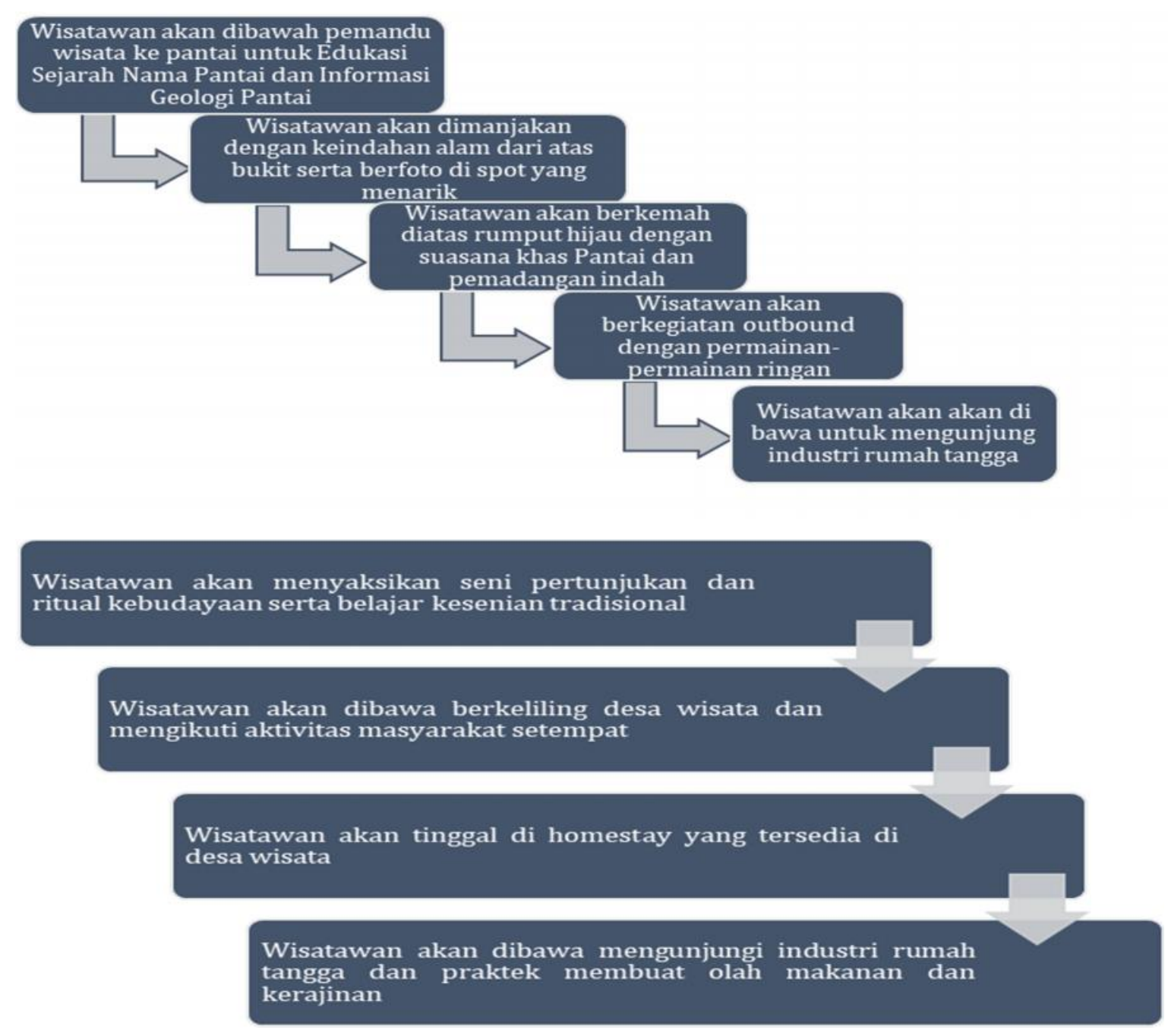

Gambar 4. Konsep Pertama dan kedua Merintis Desa Wisata Paranggupito

Sumber : analisis penelitian, 2021

Pada gambar diatas menjelaskan alur konsep dalam merintis Desa Wisata Paranggupito yang berotentasi pada pasar. Konsep ini mengusung konsep wisata edukasi agar wisatawan tidak hanya dapat menikmati semua potensi baik alam, seni dan budaya, serta mengunjungi pusat indutri rumah tangga, namun juga mengetahui informasi geologi sepanjang pesisir pantai selatan, edukasi pembuatan makanan tradisional, mengembangan kemampuan softskill dengan memberikan outbound ringan. Konsep pertama ini dibuat untuk wisatawan muda yang menyukai tantangan dan dalam jumlah kecil (10-20 wisatawan). Berikut gambaran untuk konsep kedua dalam Desa Wisata Paranggupito.
Konsep pertama dan kedua memilik kesamaan yang berorentasi pada pasar wisatawan, perbedaanya terletak pada pasar yang dituju, jika konsep pertama untuk wisatawan muda yang menyukai tantang dengan jumlah wisatawan dibatas, sedangkan untuk konsep kedua untuk jenis wisatawan massal jumlah wisatawan tidak dibatasi serta menginginkan pengalaman baru dalam berwisata. Pengalaman baru ini didapatkan wisatawan melalui interaksi langsung dengan masyarakat setempat pada saat tinggal di homestay, melakukan aktivitas bersama masyarakat setempat. Selain itu wisatawan diberi kesempatan untuk mempraktikkan kesenian, belajar membuat kerajinan, dan makanan tradisional, dan menikmat makanan tradisional. 
Pembangunan Desa Wisata Paranggupito dibagi menjadi pembangunan fisik dan pembangunan non-fisik. Pembangunan fisik adalah instalasi infrastruktur baik pada setiap obyek wisata maupun pada lingkup desa. Pembangunan fisik akan dibagi menjadi tiga tahap yakni pembangunan jangka pendek, pembangunan jangka menengah dan pembangunan jangka panjang. Sedangkan pembangunan non-fisik dibagi menjadi pengembangan sumber daya manusia, pengembangan jaringan dan pemasaran.

\section{Rencana Kegiatan Desa Wisata Paranggupito}

Rencana kegiatan dalam rangka menyiapkan dan merintis desa wisata Paranggupito dalam bentuk rencana pembangunan fisik dan non fisik guna memajukan desa wisata. Perencanaan ini dibuat secara detail, sehingga memudahkan dalam pelaksanaanya.
Rencana pembangunan fisik dilaksanakan dalam 2 tahapan yaitu rencana pendek, dan Panjang. Diharapkan rencana pembangunan fisik ini dapat mengunakan dana Desa, swadaya masyarakat, Pemda melalui Dinas Kepemudaan Dan Olahraga Dan Pariwisata Kabupaten Wonogiri, maupun bantuan dari CSR. Berikut bangunan fisik yang perlu disiapkan oleh desa wisata Paranggupito.

Table 4 Rencana Pembangunan Fisik Desa Wisata Paranggupito

\begin{tabular}{|c|c|}
\hline $\begin{array}{c}\text { Jangka pendek } \\
2021-2022 \\
\end{array}$ & $\begin{array}{c}\text { Jangan sedang } \\
2023-2024\end{array}$ \\
\hline $\begin{array}{l}\text {-Pantai Sembukan } \\
\text { Spot Foto, Camping Ground, Arena Outbond, } \\
\text { Papan Nama, MCK, Tempat Sampah, Petunjuk } \\
\text { Jalan, Papan Informasi }\end{array}$ & $\begin{array}{l}\text { Gardu Pandang, Jalur Hijau, Tempat Parkir, } \\
\text { Tempat Ibadah, Gazebo, Jalan }\end{array}$ \\
\hline $\begin{array}{l}\text { Pantai Klothok } \\
\text { Spot Foto, Tempat Sampah, Petunjuk Jalan, Papan } \\
\text { Informasi }\end{array}$ & $\begin{array}{l}\text { Bumi Perkemahan (Tanah Lapang), MCK, } \\
\text { Foodcourt, Tempat Ibadah, Tempat Istirahat, } \\
\text { Tempat Parkir, Jalan }\end{array}$ \\
\hline $\begin{array}{l}\text {-Pantai Jojogan dan Dadapan } \\
\text { Gardu pandang, Spot Foto, Tempat Sampah }\end{array}$ & $\begin{array}{l}\text { Petunjuk Jalan, Papan Informasi, MCK, Petunjuk } \\
\text { Arah Desa Wisata }\end{array}$ \\
\hline
\end{tabular}

Tabel diatas menunjukkan rencana pembangunan fisik yang akan dilakukan untuk mendukung tumbuh dan berkembangnya desa wisata Paranggupito. Pantai Sembukan menjadi prioritas utama pembangunan selama 2 tahun pertama hal ini karena Pantai Sembukan menjadi salah satu Pantai yang masuk dalam area Geosite Gunungsewu dan di pantai ini menjadi tempat dilakasanakannya tradisi Larung Agung. Saat ini kondisi pantai yang ada di desa Paranggupito sangat minim fasilitas dan sarana prasarana penunjang pariwisata, oleh sebab itu pembangunan fisik di Kawasan

pantai perlu direncanakan dengan baik termasuk model bangunan yang sesuai dengan karakteristik lokal dan ramah lingkungan.

Tidak hanya rencana pembangunan fisik desa wisata Paranggupito juga merencanakan pembangunan non fisik. Pembanguan fisik ini bertujuan untuk menyiapkan tenaga kerja professional, membangun kesadaran masyarakat serta mampu menyusun promosi yang menarik tentang desa wisata Paranggupito. Pembangunan non fisik yang akan dilakukan nantinya meliputi 3 aspek utama yaitu pembangunan sumber daya 
manusia, membangun jejaring (kemitraan) dan komunikasi antar pelaku desa wisata, serta menyusun rencana pemasaran. Berikut pembangunan non fisik yang akan dilakukan di desa wisata Paranggupito

Table 4 Rencana Pembangunan Non Fisik Desa Wisata Paranggupito

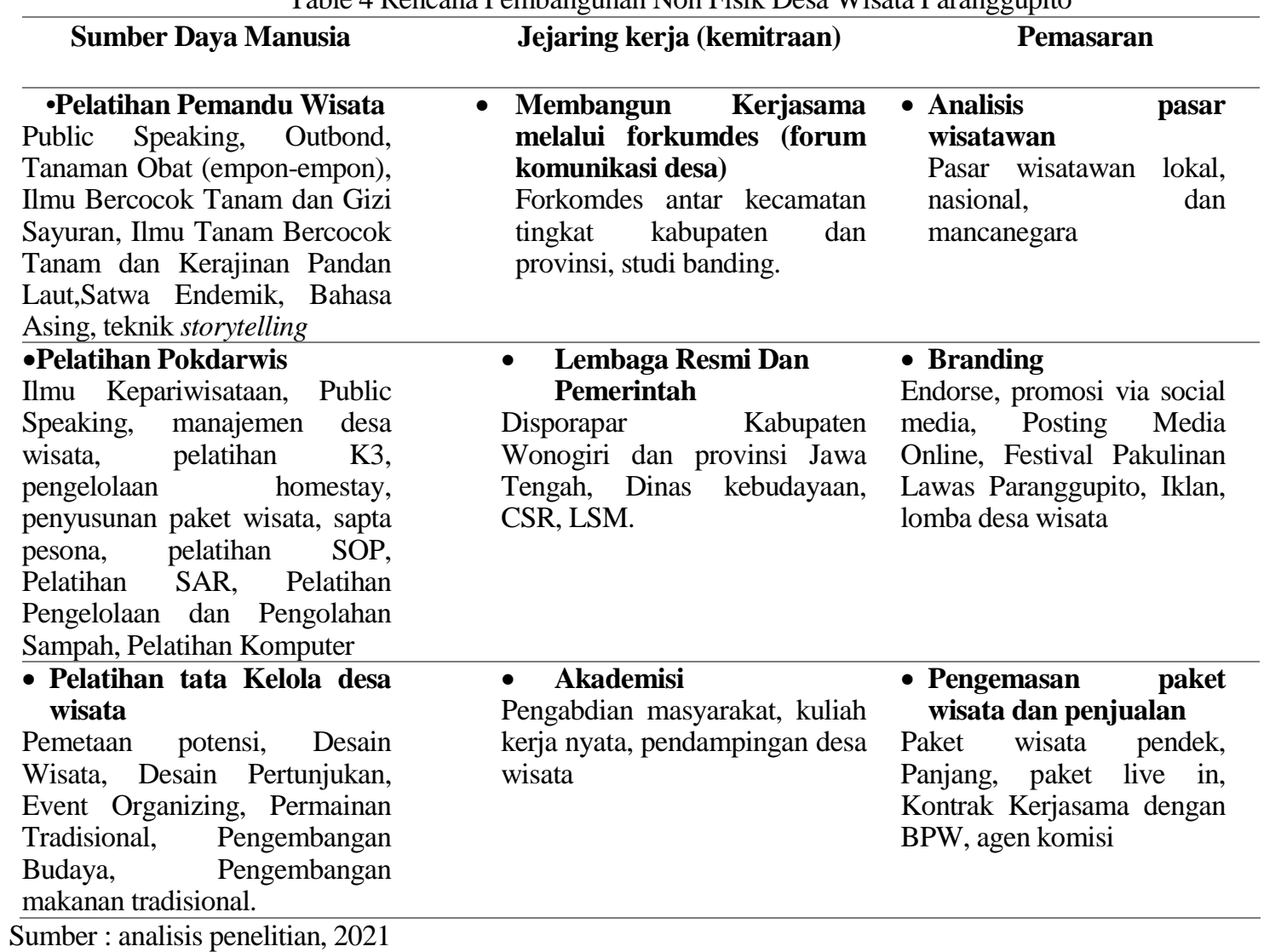

makanan tradisional.
Sumber : analisis penelitian, 2021

Dari ketiga aspek tersebut pengembangan SDM memilik porsi yang cukup besar dalam rencana pembangunan non fisik di desa wisata Paranggupito. Hal ini disebabkan karena desa Paranggupito baru mendapatkan SK dari Disporapar Kabupaten Wonogiri pada tahun 2020. Kondisi ini mempengaruhi pada kesiapan SDM dalam menerima aktivitas pariwisata, hal ini terlihar dari tidak adanya SDM yang berlatar belakang Pendidikan pariwisata. Oleh sebab itu dalam pembangunan non fisik berbagai macam bentuk pelatihan disiapkan untuk menigkatkan pengetahuan pengelola desa wisata maupun masyarakat setempat. Mengingat desa wisata Paranggupito masih dalam proses merintis, sehingga sangat perlu membangun jejaring baik dengan sesama pelaku desa wisata, pemerintah maupun Lembaga swasta dan akademisi. Agar lebih dikenal desa wisata Paranggupito perlu memilik media yang akan digunakan dalam mempromosikan potensi desa, serta menyusun paket wisata yang menarik dan beragam berdasarkan pada pasar yang akan dituju.

\section{Penyusunan Paket Wisata Desa Paranggupito}

Untuk tahap awal Desa wisata Paranggupito menyusun paket wisata baik untuk konsep pertama maupun untuk konsep ke dua berdasarkan segmen pasar yang akan dituju. Meskipun masih tergolong desa wisata baru dan rintisan, tidak ada salahnya untuk menyusun paket wisata desa, sehingga paket wisata ini nantinya yang akan dipublikasikan dan di jual melalui Kerjasama dengan BPW maupun melalui Forum komunikasi desa 


\section{wisata. Berikut beberapa pilihan paket wisata Paranggupito}

yang ditawarkan oleh desa wisata

\section{Paket Wisata Konsep 1}

Tabel 5 Paket Wisata Untuk Konsep Pertama

\begin{tabular}{|c|c|c|c|}
\hline Hari & Tour program & Include & Exclude \\
\hline Ke-1 & $\begin{array}{l}\text { Wisatawan akan disambut di Balai desa } \\
\text { dengan di sajikan welcome drink, untuk } \\
\text { bertemu dengan pemandu wisata, } \\
\text { setelah itu perjalanan menuju pantai } \\
\text { Klotok dan pantai Njojogan serta } \\
\text { makan siang dengan menu nasi berkat. } \\
\text { Menjelas sore hari wisatawan akan } \\
\text { dibawa menuju Pantai Sembukan untuk } \\
\text { menikmati matahari terbenam dan } \\
\text { membuat tenda untuk bermalem serta } \\
\text { disajikan makan malem dengan bentuk } \\
\text { nasi kondangan. }\end{array}$ & $\begin{array}{l}\text { - } \text { Tiket masuk objek wisata } \\
\text { - } \text { Pemandu outbound } \\
\text { - } \text { Game outbound } \\
\text { - } \text { Makan menu tradisional } \\
\text { - } \text { Air mineral } \\
\text { - } \text { Dokumentasi } \\
\text { - Pendopo } \\
\text { - Transpot lokal } \\
\text { Kunjungan } \\
\quad \text { jerajinan(Pembuatan gula kerajinan resin) }\end{array}$ & $\begin{array}{l}\text { - Sewa tenda } \\
\text { - Makanan } \\
\text { seafood } \\
\text { (lobster) }\end{array}$ \\
\hline $\begin{array}{l}\mathrm{Ke}- \\
2\end{array}$ & $\begin{array}{l}\text { Dihari kedua ini wisatawan akan diajak } \\
\text { untuk aktivitas outbound kemudian } \\
\text { diakhir dengan mengunjung industry } \\
\text { rumah tangga dan membeli oleh-oleh } \\
\text { kas desa. }\end{array}$ & & \\
\hline
\end{tabular}

Sumber : analisis penelitian, 2021

Harga perorang 150.000 minimal untuk (10-20 0rang)

\section{Paket Wisata konsep 2}

Tabel 6 Paket Wisata Untuk Konsep Kedua

\begin{tabular}{|c|c|c|c|}
\hline Hari & Tour program & Include & Exclude \\
\hline $\begin{array}{l}\mathrm{Ke} \quad- \\
2\end{array}$ & $\begin{array}{l}\text { Wisatawan akan disambut di Balai desa } \\
\text { dengan di sajikan welcome drink, untuk } \\
\text { bertemu dengan pemandu wisata, setelah } \\
\text { itu perjalanan menuju dusun Setro untuk } \\
\text { melihat pertunjukkan Jatilan, dan } \\
\text { menikmati makan siang dengan menu } \\
\text { tradisional yaitu Jangan Gerus. Setelah } \\
\text { itu wisatawan akan mengunjung } \\
\text { paguyuban Gejog Lesung dan Thretek } \\
\text { untuk belajar memainkan alat music } \\
\text { tradisional ini. Menjelas sore hari } \\
\text { wisatawan akan dibawa menuju } \\
\text { homestay untuk istirahat dan dimalem } \\
\text { hari acara dilanjutkan dengan makan } \\
\text { malem sambal menikmati kesenian } \\
\text { tembang jawa } \\
\text { Dihari kedua ini wisatawan akan diajak } \\
\text { untuk belajar membuat kerajinan resin, } \\
\text { membuat gula jawa, mengunjung } \\
\text { pembudidayaan bonsai kemudian diakhir } \\
\text { dengan membeli oleh-oleh kas desa. }\end{array}$ & $\begin{array}{ll}\text { - } & \text { Homestay } \\
\text { - } & \text { Pertunjukkan kesenian } \\
\text { - } & \text { Pemandu } \\
\text { - } & \text { Welcome drink } \\
\text { - } & \text { Makan menu tradisional } \\
\text { - } & \text { Air mineral } \\
\text { - } & \text { Dokumentasi } \\
\text { - } & \text { Pendopo } \\
\text { - } & \text { Transpot lokal } \\
\text { - } & \text { Kunjungan sentra } \\
& \text { kerajinan (Pembuatan } \\
& \text { gula jawa, kerajinan } \\
& \text { resin) }\end{array}$ & 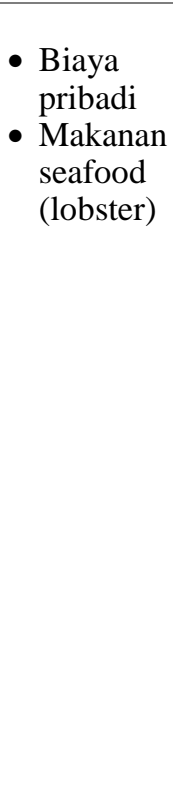 \\
\hline
\end{tabular}
Harga perorang 230.000 minimal untuk 30 0rang

Sumber : analisis penelitian, 2021 


\section{SIMPULAN}

Merinitis desa wisata bukan hal yang mudah, diperlukan konsistensi, ketekunan, dan kebersamaan untuk memasukkan desa wisata, hal ini juga yang terjadi pada Desa wisata di Kabupaten Wonogiri sejak adanya SK pembentukan desa wisata dari Dinas Pemuda dan Olahraga dan Pariwisata Kabupaten Wonogiri ditahun 2020. Desa wisata Paranggupito saat ini sedang giat untuk mengembangan pariwisata, meskipun serba terbatas karena adanya Pandemi Covid19. Melihat antusias dan respon masyarakat yang bersemangat memajukan desa wisata, hal ini yang menjadi modal utama dalam merintis desa wisata, namun sayangnya tidak banak pemuda-pemudi desa yang terlibat dalam kegiatan seni budaya. Bentuk wisata yang ditawarkan Desa Wisata Paranggupito adalagh wisata edukasi yang memberikan pengalaman baru kepada wisatawan saat berkunjungan dan melakukan aktivitas wisata didesa ini.

Potensi desa wisata Paranggupito sangat beragam potensi alam yang berupa Pantai berbatu yang sangat cocok untuk aktivitas spot rock fishing karena bentukkan Pantai berbatu dan masuk dalam Global Geopark Network. Potensi alam yang ada dipadu dengan budaya ritual Larung Agung yang dilakukan setiap malem 1 Suro menjadi daya tarik tersendiri bagi wisatawan. Potensi budaya yang dapat di explor wisatawan diantaranya adalah Jatilang, tembang Jawa, Karawitan, Gejug Lesung, dan Thretek. Sedangkan industry rumah tangga yang nantinya akan ditawarkan kepada tamu sebagai aktivitas wisata adalah kerajinan resin, membuat gula jawa, membuat janur, dan budidaya bonsai. Namun sayangnya sebagai besar masyarakat yang mengambil bagian dan kelompok kesenian adalah warga setempat yang sudah lanjut usia, sedangkan warga muda-mudi sedikit yang memilik keinginan untuk belajar dan melestarikan seni budaya setempat yang nantinya akan di tawarkan kepada tamu.

Dalam merintus desa wisata Paranggupito ini dibuat dalam 2 konsep yang berorentasi pada pasar wisatawan yang akan dituju, yaitu konsep 1 yang lebih menekankan pada wisata edukasi dan petualangan dengan pasar yang dituju adalah anak muda yang menyukai petualangan. Paket ini dijual dengan harga 150 untuk 1020 wisatawan. Konsep yang kedua adalah untuk wisatawan massal yang dengan aktivitas dominan adalah edukasi seni pertunjukkan sehingga wisatawan diberi kesempatan untuk belajar menarik dan memakinkan musik serta edukasi membuat makanan kerajinan dan makanan olah. Selain menyusun paket wisata rencana awal yang akan dilaksanakan desa wisata Paranggupito dengan Menyusun rencana pembangunan fisik yang akan dilakukan pada data tarik wisata pantai Sembukan, Jojokan dan pantai Ndadapan. Selain itu pembangunan non fisik juga akan dilakukan meliputi pembangunan SDM baik ketrampilan Teknik maupun manajerial bagi pengelola desa wisata, membangun jejaring Kerjasama, dan menyusun media pemasaran yang akan digunakan.

\section{REFERENSI}

Anggit, K.P., \& Suswanto (2020) Pengembangan Desa Wisata Berbasis Pemberdayaan Masyarakat Desa Wisata Kaki Langit Padukuhan Mangunan, 7 (1), 221-240. https://doi.org/10.24843/JUMPA.2020 .v07.i01.p10

Azzar, A., \& Taufan, D.S.,\& Fauzi, R (2020) Identifikasi Potensi dan Status Pengembangan Desa Wisata di Kabupaten Lombok Tengah, Nusa Tenggara Barat, 4 (2), 84-98. https://doi.org/10.29244/jp2wd.2020.4 $.2 .84-98$

BAPPENAS, Kementerian Pariwisata, Kementerian Desa, Pembangunan Daerah Tertinggal dan Transmigrasi, Kementerian Lingkungan Hidup dan Kehutanan, dan Panorama Foundation. (2015). Biografi Ulama Nusantara. 
Asisten Deputi Urusan kabupaten wonogiri. Portal Berita Ketenagalistrikan dan Aneka Usaha Pemerintah Provinsi Jawa Tengah. Kementerian Koperasi dan UKM Republik Indonesia.

Badan Pusat Statistik Kabupaten Wonogiri. (2020) Kabupaten Wonogiri Dalam Angka Tahun 2020

Desa Paranggupito (2020) Masterplan Desa Parangguito https://jatengprov.go.id/beritaopd/4pantai-menawan-di-ujung-selatanwonogiri/

Peraturan Menteri Desa, Pembangunan Daerah Tertinggal, Dan Transmigrasi Republik Indonesia Nomor 11 Tahun 2019 Tentang Prioritas Penggunaan Dana Desa Tahun 2020

Dinas Pemuda Dan Olahraga Dan Pariwisata Provinsi Jawa Tengah (2019) Neraca Satelit Pariwisata Daerah Provinsi Jawa Tengah

Global Geopark Network International Association (2020) Global Geopark Network diambil dari https://www.visitgeoparks.org/

Pemerintah Provinsi Jawa Tengah (2017) 4 pantai menawan di ujung selatan

Peraturan Daerah Provinsi Jawa Tengah No. 2 Tahun 2019 tentang pemberdayaan desa wisata di Provinsi Jawa Tengah

Ranang, H.D., Darmawan, D., Kadek, W.,\& Putu, W.A (2020) Sustainable Tourist Villages Management Based On Javanese Local Wisdom 'Memayu Hayuning Bawono Best Practice Of Desa Wisata Pentingsari, Yogyakarta, 7 (2) 41-53 https://doi.org/10.18510/ijthr.2020.72 